\title{
The effect of independent auditor's report on profit distribution policy: Evidence from Tehran Stock Exchange
}

\author{
Parviz Piri $^{\mathrm{a}^{*}}$, Mansour Gargaz ${ }^{\mathrm{b}}$, Mohhammad Tagi Mirfendresky ${ }^{\mathrm{c}}$ and Abbas Aalizadeh ${ }^{\mathrm{d}}$
}

\author{
${ }^{a}$ Assist. Prof. \& Faculty Member, Department of Accounting, University of Urmia, Urmia, Iran \\ ${ }^{b}$ Assist. Prof. \& Faculty Member, Department of Accounting, Aliabad Katol Branch, Islamic Azad University, Aliabad Katol, Iran \\ ${ }^{c}$ Department of Accounting, Gorgan Branch, Islamic Azad University, Gorgan, Iran \\ ${ }^{d}$ Masters in Accounting
}

\section{H R O N I C L E}

Article history:

Received January 4, 2014

Accepted 1 June 2014

Available online

June 52014

Keywords:

Tehran Stock Exchange

EPS

Auditor Report

Dividend Policy

DPS

\section{A B S T R A C T}

\begin{abstract}
Profit distribution is one of the most debatable subjects in financial field. Opposite theoretical models that sometimes, do not have a strong empirical support look for the explanation of corporate dividend policy. In this paper, the relationship between profit sharing policy and auditor's and managers' expected profit is studied. The study gathers the necessary information of 99 firms listed on Tehran Stock Exchange over the period 2002-2011. The implementation of regression analysis shows that there was more explanatory power of auditors' expected profit than managers' expected profit in dividends. The results also show that there was no meaningful difference between auditors` expected profit and managers` expected profit.
\end{abstract}

(C) 2014 Growing Science Ltd. All rights reserved.

\section{Introduction}

Profit distributing is one of the most debatable subjects in financial field (Fama \& French, 2001). Opposite theoretical models that sometimes, do not have a strong empirical support look for the explanation of corporate dividend policy. The relative importance of cash-flow uncertainty in payout policy has gained little attention in empirical studies, while survey studies such as Lintner (1956) and Brav et al. (2005) indicated its importance. Chay and Suh (2009) presented some evidence that cashflow uncertainty was an important cross-sectional determinant of corporate payout policy. They reported that across countries, cash-flow uncertainty, as proxied by stock return volatility, maintained a negative effect on the amount of dividends as well as the probability of paying dividends. The effect of cash-flow uncertainty on dividends was normally stronger than the effect of other potential determinants of payout policy such as the earned/contributed capital mix, agency conflicts, and 
investment opportunities. They also reported that the impact of cash-flow uncertainty on dividends was distinct from the impact of a firm's financial life-cycle stage. Bradley et al. (1998) explored the effect of expected cash-flow volatility as a determinant of dividend policy and reported that, given the existence of a stock-price penalty associated with dividend cuts, managers normally pay out lower levels of dividends when future cash flows become less certain.

Fenn and Liang (2001) investigated how corporate payout policy was influenced by managerial stock incentives using data on more than 1,100 nonfinancial firms over the period 1993-97. They reported that management stock ownership was associated with higher payouts by firms with potentially the biggest agency problems. They also reported that management stock options were associated with the composition of payouts. They also reported a strong negative relationship between dividends and management stock options and a positive relationship between repurchases and management stock options. The results suggested that the growth in stock options could help us explain the rise in repurchases at the expense of dividends.

Barclay and Smith Jr (1988) argued that there were costs associated with open-market-repurchase programs, since they provided managers with opportunities to implement inside information to benefit themselves at stockholders' expense. They offered evidence recommending that bid-ask spreads widen around repurchase announcements. Frankfurter and Wood Jr (2002) determined whether the method of analysis employed, sample period, and/or data frequency are responsible for this inconsistent support. Consler et al. (2011) compare the relative power of operating cash flow and earnings in the prediction of dividends and reported that cash flow per share could produce a better fit than earnings per share, but it cannot be said how much better.

\section{The proposed study}

In this paper, we study the relationship between profit sharing policy and auditor's and managers' expected profit. The proposed study collects the necessary information from the firms whose shares were listed on Tehran Stock Exchange and they were profitable during the period of study.

We consider considered the information of the firms whose fiscal year was ended on March and there was no change on their fiscal years. The study has gathered the necessary information of 99 firms listed on Tehran Stock Exchange over the period 2002-2011. In this study, earning per share (EPS) is the independent variable, which is considered in two forms of $\mathrm{EPS}_{\mathrm{r}}$ and $\mathrm{EPS}_{\mathrm{h}}$, and they are calculated as follows,

$\mathrm{EPSr}=$ Net profit after tax deduction/average number of outstanding shares,

$\mathrm{EPS}_{\mathrm{h}}=($ Net profit + non-accounted incomes - Non-accounted losses $) /$ average number of outstanding shares.

Dividend per share (DPS) is also considered as the dependent variable and it is calculated as follows,

DPS $=($ Net profit approved for distribution $) /$ average number of outstanding shares.

The proposed study considers four control variables. Size is the first control variable, which is calculated by taking natural logarithm on total assets. Debt is the second variable, which is the ratio of total liabilities on total assets. Invest is the third variable, which is calculated as the ratio of market value on book value of firm. Finally, Liquidity is the last control variable, which is calculated as the ratio of the current assets on the current liabilities. There are two hypotheses for the proposed study of this paper as follows,

1. $\mathrm{EPS}_{\mathrm{h}}$ policy is a better prediction for DPS compared with $\mathrm{EPS}_{\mathrm{r}}$.

2. There is a meaningful difference between $\mathrm{EPS}_{\mathrm{h}}$ and $\mathrm{EPS}_{\mathrm{r}}$. 
The study uses regression analysis to examine two hypotheses of the survey as follows,

DPS $=\alpha+\beta_{1}$ EPSr $_{i t}+\beta_{2}$ EPSh $_{i t}+\beta_{3}$ INVEST $_{i t}+\beta_{4}$ SIZE $_{i t}+\beta_{5}$ DEBT $_{i t}+\beta_{6}$ LIQUDITY $_{i t}+\varepsilon_{i t}$.

Table 1 demonstrates the summary of some basic statistics,

\section{Table 1}

The summary of some basic statistics

\begin{tabular}{lccccccc}
\hline Statistics & DPS & EPS $_{\mathrm{r}}$ & EPS $_{\mathrm{h}}$ & Invest & Size & Debt & Liquidity \\
\hline Mean & 883.470 & 1722.741 & 1289.371 & 14.031 & 12.944 & 0.655 & 1.295 \\
Standard deviation & 4343.120 & 21.364 .40 & 11848.21 & 232.445 & 1.433 & 0.1690 & 1.485 \\
Skewness & 29.068 & 31.263 & 31.002 & 23.430 & 0.820 & -0.5124 & 24.724 \\
Kurtosis & 889.393 & 981.231 & 970.300 & 566.939 & 4.670 & 3.669 & 710.952 \\
Jarque- Bera & 32516385 & 39594862 & 38715808 & 13195894 & 226.037 & 61.788 & 20754232 \\
Sig. & 0.0001 & 0.0001 & 0.0001 & 0.0001 & 0.0001 & 0.0001 & 0.0001 \\
\hline
\end{tabular}

As we can observe from the results of Table 1, all variables are normally distributed and we may use regression analysis to test the hypothesis of the survey. In addition, Table 2 demonstrates the results of two other statistics to verify whether the data are stationary or not and the results confirm that all data are stationary.

Table 2

The results of Levin and Philips tests

\begin{tabular}{lccccl}
\hline \multirow{2}{*}{ Variable } & \multicolumn{2}{c}{ Chaw test } & \multicolumn{2}{c}{ Philips } & \multirow{2}{*}{ Result } \\
& F statistics & Prob. & F statistics & Prob. & \\
\hline DPS & -125.6 & 0.0001 & 523.58 & 0.0001 & Stationary \\
EPS $_{\mathrm{r}}$ & 6.254 & 0.0001 & 456.97 & 0.0001 & Stationary \\
EPS $_{\mathrm{h}}$ & -41.17 & 0.0001 & 504.71 & 0.0001 & Stationary \\
Invest & -21.28 & 0.0001 & 371.96 & 0.0001 & Stationary \\
Size & -13.12 & 0.0001 & 367.62 & 0.0001 & Stationary \\
Debt & -17.68 & 0.0001 & 338.85 & 0.0001 & Stationary \\
Liquidity & -44.885 & 0.0001 & 378.431 & 0.0001 & Stationary \\
\hline
\end{tabular}

\section{The results}

In this section, we present details of our implementation of the regression analysis and testing two hypotheses of the survey. Note that our survey shows there was autocorrelation between the residuals of the regression model. Therefore, we take a difference between the data, i.e. AR(1), to remove the effect of autocorrelation. Table 3 shows details of our survey using fixed effect method.

Table 3

The summary of regression analysis on Eq. (4)

\begin{tabular}{cccc}
\hline Variable & $\beta$ & t-value & Sig. \\
\hline EPS audit & 0.4891 & 15.6565 & 0.0001 \\
EPS & 0.2825 & 8.375 & 0.0001 \\
Invest & 0.0012 & 0.0344 & 0.9725 \\
Size & 14.1291 & 1.1433 & 0.2532 \\
Debt ratio & -156.6330 & -3.287 & 0.0011 \\
Liquidity & 3.2387 & 0.7797 & 0.4358 \\
Intercept & -89.221 & -0.5071 & 0.6122 \\
$A R(1)$ & -0.0026 & -4.2367 & 0.0001 \\
\hline $\mathrm{R}^{2}=0.9662$ Adjusted $\mathrm{R}^{2}=0.9617$ Durbin-Watson $=1.9525$ F-value $=213.5927$ P-value $=0.000$ & &
\end{tabular}

The results of Table 3 indicate the independent variables could approximately describe $96 \%$ of the dependent variable. In addition Durbin-Watson value is within the acceptable limit and F-value is 
statistically significant, which means there is a linear relationship between independent and dependent variables.

\subsection{Testing the first hypothesis}

The first hypothesis of the survey investigates the effects of EPS reported by auditor compared with the one reported by firm on DPS. As we can observe, the first one represents higher value than the second EPS. Therefore, we can confirm the first hypothesis of the survey.

\subsection{Testing the second hypothesis}

The second hypothesis of the survey investigates whether there is a meaningful difference between the mean of EPS reported by auditor and firm. To verify this, we have used Leven test and the result of F-value is equal to 0.463 with $\mathrm{P}$-value $=0.496$. Therefore, we do not have any evidence to believe there was any difference between these two EPS.

\section{Conclusion}

One of the most important issues on investment decision is associated with net profit distributed among shareholders. Investors also wish to find out about the reliability of the net profit reported by firm and would like to see the same figures by independent auditors. This paper has examined whether EPS reported by auditors was a better predictor of DPS or not. Using regression analysis, the study has confirmed that the auditors' figures provide better results compared with the one reported by firm but further investigation has also indicated that there was no meaningful between the earnings reported by firm and by auditor.

\section{Acknowledgement}

The authors would like to thank the anonymous referees for constructive comments on earlier version of this paper.

\section{References}

Barclay, M. J., \& Smith Jr, C. W. (1988). Corporate payout policy: Cash dividends versus openmarket repurchases. Journal of Financial Economics,22(1), 61-82.

Bradley, M., Capozza, D. R., \& Seguin, P. J. (1998). Dividend policy and cash-flow uncertainty. Real Estate Economics, 26(4), 555-580.

Brav, A., Graham, J., Harvey C., \& Michaely, R. (2005). Payout policy in the 21st century. Journal of Financial Economics, 77, 483-527.

Chay, J. B., \& Suh, J. (2009). Payout policy and cash-flow uncertainty. Journal of Financial Economics, 93(1), 88-107.

Consler, J., Lepak, G. M., \& Havranek, S. F. (2011). Earnings per share versus cash flow per share as predictor of dividends per share. Managerial Finance,37(5), 482-488.

Fama, E. F., \& French, K. R. (2001). Disappearing dividends: changing firm characteristics or lower propensity to pay?. Journal of Financial economics,60(1), 3-43.

Fenn, G. W., \& Liang, N. (2001). Corporate payout policy and managerial stock incentives. Journal of financial economics, 60(1), 45-72.

Frankfurter, G. M., \& Wood Jr, B. G. (2002). Dividend policy theories and their empirical tests. International Review of Financial Analysis, 11(2), 111-138.

Lintner, J. (1956). Distribution of incomes of operations among dividends, retained earnings, and taxes. American Economic Review, 46, 97-113. 